Editorial

\title{
The Transformative Forces of Migration: Refugees and the Re-Configuration of Migration Societies
}

\author{
Ulrike Hamann * and Gökçe Yurdakul \\ * Corresponding author \\ Submitted: 16 March 2018 | Published: 29 March 2018
}

Department of Diversity and Social Conflict, Institute for Social Sciences, Humboldt-Universität zu Berlin, 10099 Berlin, Germany; E-Mails: ulrike.hamann@sowi.hu-berlin.de (U.H.), gokce.yurdakul@sowi.hu-berlin.de (G.Y.)

\begin{abstract}
In this thematic issue, we attempt to show how migrations transform societies at the local and micro level by focusing on how migrants and refugees navigate within different migration regimes. We pay particular attention to the specific formation of the migration regimes that these countries adopt, which structure the conditions of the economic, racialised, gendered, and sexualized violence and exploitation during migration processes. This interactive process of social transformation shapes individual experiences while also being shaped by them. We aim to contribute to the most recent and challenging question of what kind of political and social changes can be observed and how to frame these changes theoretically if we look at local levels while focusing on struggles for recognition, rights, and urban space. We bring in a cross-country comparative perspective, ranging from Canada, Chile, Spain, Sweden, Turkey, and to Germany in order to lay out similarities and differences in each case, within which our authors analyse these transformative forces of migration.
\end{abstract}

\section{Keywords}

citizenship; migration; refugees; transformation

\section{Issue}

This editorial is part of the issue "The Transformative Forces of Migration: Refugees and the Re-Configuration of Migration Societies", edited by Ulrike Hamann and Gökçe Yurdakul (Humboldt University of Berlin, Germany).

(C) 2018 by the authors; licensee Cogitatio (Lisbon, Portugal). This article is licensed under a Creative Commons Attribution 4.0 International License (CC BY).

Migration has deep impacts on social structures and socio-political power relations in departure, transit, and arrival countries. Migrants and refugees contest and transform dominant notions of the nation-state, state control, national sovereignty, citizenship, and participation. In migration processes, both newcomers and citizens address issues of equality and inclusion while renegotiating the meaning of (national) belonging and citizenship in terms of social and civil rights. Such processes can bring up unexpected alliances between social actors and new definitions of "who we are." We observe processes of transformation of migration societies through such everyday practices and state decisions on who belongs and who does not belong to polity.

In this thematic issue, our focus lays on the challenges to and transformation of societies, which are shaped by migration, the regimes that try to regulate it, and by the struggles of migrants, refugees, and solidarity movements for social inclusion and participation. In this framework, social transformation has two main components, one is how newcomers transfer society, this is what immigrant and refugee-receiving countries are experiencing. The other is how societies create specific subject positions through their legal, political decisions and through engaging with social boundaries and cultural repertoires (Lamont \& Molnar, 2002; Yurdakul, 2013).

Depending on the specific socio-political and legal context of the destination country, the relations between immigrants and their new societies change dramatically. In this thematic issue, we attempt to show how migrants and refugees navigate within these migration regimes, specifically, in times of neoliberal transfor- 
mations of the welfare state and with right-wing strategies of Othering in terms of class, gender, and racialization present. We also pay particular attention to the specific formation of the migration regimes that these countries adopt, which structure the conditions of the economic, racialised, gendered, and sexualized violence and exploitation during migration processes. This interactive process of social transformation shapes individual experiences while also being shaped by them.

Building on our previous work (Hamann \& Karakayali, 2016; Yurdakul, Römhild, Schwanhäusser, \& zur Nieden, 2018) and the inspiring work of others (see e.g. Ataç, Rygiel, \& Stierl, 2016; Fiedler et al., 2017) on the issue of transformation since the long summer of migration (Kasparek \& Speer, 2015), we aim to contribute to the most recent and challenging question of what kind of political and social changes can be observed and how to frame these changes theoretically if we look at local levels while focusing on struggles for recognition, rights, and urban space within societies shaped by migration. We bring in a cross-country comparative perspective, ranging from Canada, Chile, and Spain to Sweden, Turkey or Germany. Such a cross-country perspective is useful in order to see how each country case differs from or resembles each other in terms of their historical shifts, policy changes, and their reaction towards immigrant struggles. Many contributions have applied a methodological approach developed in critical migration studies that goes "beyond the established paradigms of both traditional and critical migration studies to create different relationships with migrants and migrants' struggles" (Casas-Cortes et al., 2015 , p. 57). The analytical "perspective of migration" (Casas-Cortes et al., 2015, p. 69) shifts the focus of traditional migration research, in which migration is defined as "a peripheral phenomenon that appears at the margins of society" (Römhild, 2009, p. 225), to a perspective that regards migration as a constituting force within societies. This perspective can open up new ways of looking at the internal make-up of a society by seeing it as inevitably and irrevocably shaped by migration.

We focused on answering three major questions in our thematic issue: The first question focuses on the change of political discourses and practices that accompany the arrival of refugees and immigrants in their destination countries. The authors of this issue paid specific interest in political-economic discourses in arrival countries (Scarpa \& Schierup, 2018) or discourses on citizenship (Koser Akcapar \& Simsek, 2018), the practices of citizens in solidarity (Rast \& Gorashi, 2018; Schmidtke, 2018) or those of the struggles of migrants (Bouali, 2018; Wilcke, 2018). In focusing on these three fields of change, we put them in a conversation on central social conflicts. Relatedly, the second question is how economic conditions and social and civil rights have changed after the arrival of refugees and immigrants. Authors showed how citizenship policies change, how austerity measures are forming the conditions of the crisis of administration after the long summer of migration, and how social rights and local administrative reality conflicted with each other in the realm of housing. Thirdly, we focused on the transformation within the cities. In this way, we saw the effects of specific urban politics regarding the struggles of refugees and immigrants in the cases of sanctuary cities (Bauder \& Gonzalez, 2018), or refugees' housing problems (El-Kayed \& Hamann, 2018). The cross-cutting issues in answering these questions have been dealing with racist politics and attitudes; the effects of neoliberal policy-making on immigrants and refugee/immigrant struggles in negotiating their rights and fighting against racism, and for acceptable labour conditions (Bouali, 2018). The answers to these questions are overlapping in each article, but cross-cutting all of them.

These three questions can only be framed in a solid theoretical base. Engin Isin (2018) starts a new stream of thinking society not from a static geography, but from the mobility of people. Centuries of migration, diaspora, traveling, and flight have made mobility the norm rather than the exception, a reflection leading him to a new concept of thinking society through migration. From this crucial turn of perspective he asks: why were 'mobile peoples' constructed as an exception in the first place? His new concept is a logical step from his influential work on citizenship that can rather be seen as a practice, as acts, practised by people who are present with or without a formal state membership (Isin \& Nielsen, 2008). With his new concept of 'mobile peoples' Isin goes one step further. He not only theorises the way of practicing participation in a social entity from each status as an act of becoming part of this entity. Now he conceptualises this very social and political entity as constituted by migration itself. His change of perspective from the static territorial nation state as the defining entity for the central social, political, or economic reference towards mobility as the driver for political, cultural, and social change helps to question concepts that seem to dominate modern thinking. This detailed unpacking of the processes of creating a people is supplemented by Isin when following the thinking of Agamben, Rancière, and Laclau of how a part becomes a whole or part of a whole entity. Their writings still leave him puzzled with the problem, that in order to become part of a political realm 'mobile people' need in this stream of thinking to settle or remain alternatively out of politics. His attempt to approach this impasse is to conceive citizenship, or it's opposite, not as static, but as a spectrum through which many people move for many reasons. In his view, the epistemic problem of conceiving mobility as constitutive is also a problem of a historiography that binds a people to a (imaginary) territory. What we need is a historiography of mobile people.

The leading theoretical article by Isin as a challenge to the modern theorization of the immigrant as an exception reflects the general concern of this thematic issue. We aim to bring not only this theoretical new approach of mobile people, accompanied by several others, from 
ongoing critical debates such as sanctuary cities, immigrant struggles, and multiplication of borders (Mezzadra $\&$ Neilson, 2013). The authors of this issue moreover contribute with their profound, empirically based analysis to these challenging concepts.

The thematic issue continues after Engin Isin's contribution with an article by Harald Bauder and Dayana Gonzalez (2018) on Sanctuary Cities. The term refers to many different practices of urban politics towards federal repressive migration regimes. The authors clarify the concept by categorising Sanctuary Cities by legality, discourse, identity, and scale, and discuss this definition along their empirical work on three cities outside the well-known and discussed context of the USA, Canada and, the UK by analysing the practices of cities in Spain, Chile, and Germany.

Following the urban dimension of this issue, Nihad ElKayed and Ulrike Hamann (2018) address the questions of where and how to arrive in a society and how the border multiplies into the urban space. The authors analyse the regulatory practices of accommodating refugees in Germany on the local, federal, and state level and study how the arrival of refugees is managed through a diverse set of actors, legislation, and administrational decisions. They follow the question of how refugees find a way out of the camps into independent living in the cities of arrival. Considering housing and accommodation as one of the priorities that refugees talk about after their arrival, (Schiefer, 2017, p. 3) this touches a highly relevant issue for the arrival process.

Oliver Schmidtke (2018), also at the urban dimension of migration, studies the ways of arrival of refugees in Canada by focusing on civil society. Following two specific programs that are in place to welcome newcomers into the Canadian society (Neighborhood Houses and the Privately-Sponsored Refugee program), he elaborates on how socio-economic dynamics and urban governance can work in favour of refugees to develop their voice and agency within Canadian society.

Holger Wilcke's (2018) work takes us to another form of civil society, that of illegalised workers and labour conditions. He focuses on a struggle of undocumented migrants in Germany in 2002 that resulted in a change in union politics of representation of (illegalised) migrant workers. The successful intervention of a group, usually trying to be an invisible part of society-the undocumented workers-into a national union meeting has resulted in an actual change of the politics of the union. Analysing this struggle with Rancière as becoming a part by those who have no part, Wilcke follows some of the activists of that time and adds additional voices from current undocumented workers and their everyday struggles.

Similarly, by combining the concepts of immigrant struggles and border regimes, Celia Bouali (2018) studies an aspect of labour struggles of migrants in Berlin. Her focus lies in contrast to many other articles of this thematic issue not on refugee migration, but on an often- neglected migration within the EU, more specifically from the EU-south to EU-north. Bouali demonstrates through the perspective of a self-organized migrant workers' strike group, how the internal workings of the border regime affect the labour conditions of EU-citizens that migrate within the EU.

Immigrant struggles open up the questions on changing social and economic relations in immigrant receiving countries. Sebnem Koser Akcapar and Dogus Simsek (2018) highlight in their contribution the changes in the law on citizenship that Turkish politics is undergoing due to the recent refugee migration from Syria. We can also see how class plays a significant role in migration and citizenship politics, and what they demonstrate based on the interrelatedness of socio-economic status and legal status. Can the changes in citizenship law that follow economic calculations still be linked to a broader change of the notion of citizenship? The authors follow the perspective of migration methodologically by gaining their empirical data from interviews with Syrian refugees.

The discourse of citizenship rights is articulated in the Netherlands through the notion of participation. Maria Charlotte Rast and Halleh Gorashi (2018) are studyingbased on empirical fieldwork-what kind of challenges and chances are laid out by volunteering "community initiatives" that are aiming to foster participation and inclusion of refugees. The article shows how the intentions of local initiatives of volunteers can get confused with the intentions and perspectives of newcomers/refugees for whom these initiatives have been created. It can be taken as an example of how the purpose of organising "participation" does not meet the different perceptions, power relations in place, and goals that undermine volunteer work, even though one of the goals is to create an inclusive space.

Regarding economic discourse, Simone Scarpa and Carl-Ulrik Schierup (2018), as economists, shed an analytical light on the narratives of right wing populist discourses against migration. Their contribution builds against a widespread discourse in Sweden stretching the assumed 'burden' that refugee migration puts on the welfare state. Challenging that narrative means for the authors to follow the changes of the welfare system into the past, to the neoliberal transformations that have been made in order to establish what the authors call a consolidation state. The authors convincingly reveal how the discourse on a "systemkollaps" or "breakdown", which is allegedly near due to arriving Syrian refugees, is covering a much older process of weakening of the welfare state due to austerity politics beginning in the 1990s.

We believe that the newly introduced or implemented concepts (mobile people, sanctuary cities, multiplication of borders, among others); the combining of solid theoretical framework with recently collected empirical data; as well as the cross-country perspective of this thematic issue make an innovative and important contribution to migration studies. 


\section{References}

Ataç, I., Rygiel, K., \& Stierl, M. (2016). Introduction: The contentious politics of refugee and migrant protest and solidarity movements: Remaking citizenship from the margins. Citizenship Studies, 20(5), 527-544. https://doi.org/10.1080/ 13621025.2016 .1182681

Bauder, H., \& Gonzalez, D. (2018). Municipal responses to 'illegality': Urban sanctuary across national contexts. Social Inclusion, 6(1), 124-134.

Bouali, C. (2018). Facing precarious rights and resisting EU 'migration management': South European migrant struggles in Berlin. Social Inclusion, 6(1), 166-175.

Casas-Cortes, M., Cobarrubias, S., Garelli, G., Grappi, G., Heller, C., Hess, S., . . . Tazzioli, M. (2015). New keywords: Migration and borders. Cultural Studies, 29(1), 55-87. https://doi.org/10.1080/ 09502386.2014 .891630

El-Kayed, N., \& Hamann, U. (2018). Refugees' access to housing and residency in German cities: Internal border regimes and their local variations. Social Inclusion, 6(1), 135-146.

Fiedler, M., Georgi, F., Hielscher, L., Ratfisch, P., Riedner, L., Schwab, V., \& Sontowski, S. (2017). Umkämpfte Bewegungen nach und durch EUropa. Zur Einleitung. movements. Journal for Critical Migration and Border Regime Studies, 3(1).

Hamann, U., \& Karakayali, S. (2016). Practicing Willkommenskultur: Migration and solidarity in Germany. Intersections. East European Journal of Society and Politics, 2(4), 69-86.

Isin, E. (2018). Mobile peoples: Transversal configurations. Social Inclusion, 6(1), 115-123.

Isin, E. F., \& Nielsen, G. M. (Eds.). (2008). Acts of citizenship. New York: Zed Books.

Kasparek, B., \& Speer, M. (2015). Of hope. Hungary and the long summer of migration. bordermonitoring.eu. Retrieved from http://bordermonitoring.eu/ ungarn/2015/09/of-hope-en

Koser Akcapar, S., \& Simsek, D. (2018). The politics of Syrian refugees in Turkey: A question of inclusion and exclusion through citizenship. Social Inclusion, 6(1), 176-187.
Lamont, M., \& Molnar, V. (2002) The study of boundaries across the social sciences. Annual Review of Sociology, 28, 167-195.

Mezzadra, S., \& Neilson, B. (2013). Border as method, or, the multiplication of labor. Durkheim: Duke University Press.

Rast, M. C., \& Gorashi, H. (2018). Dancing with 'the other': Challenges and opportunities of deepening democracy through participatory spaces for refugees. Social Inclusion, 6(1), 188-198.

Römhild, R. (2009). Aus der Perspektive der Migration: Die Kosmopolitisierung Europas. In S. Hess, J. Binder, \& J. Moser (Eds.), No integration?! Kulturwissenschaftliche Beiträge zur Integrationsdebatte in Europa (pp. 225-238). Bielefeld: Transcript.

Scarpa, S., \& Schierup, C.-U. (2018). Who undermines the welfare state? Austerity-dogmatism and the Uturn in Swedish asylum policy. Social Inclusion, 6(1), 199-207.

Schiefer, D. (2017). Was wirklich wichtig ist: Einblicke in die Lebenssituation von Flüchtlingen. Berlin: Robert Bosch-Stiftung, Sachverständigenrat deutscher Stiftungen für Integration und Migration (SVR). Retrieved from http://www.bosch-stiftung. de/sites/default/files/publications/pdf_import/SVR_ Was_Fluechtlingen_wirklich_wichtig_ist.pdf

Schmidtke, O. (2018). The civil society dynamic of including and empowering refugees in Canada's urban centres. Social Inclusion, 6(1), 147-156.

Wilcke, H. (2018). Imperceptible politics: Illegalized migrants and their struggles for work and unionization. Social Inclusion, 6(1), 157-165.

Yurdakul, G. (2013). Jews and Turks in Germany: Immigrant integration, political representation and $\mathrm{mi}-$ nority rights. In A. Salvatore, O. Schmidtke \& H.-J. Trenz (Eds.), Rethinking the public sphere through transnationalizing process: Europe and beyond (pp. 251-268). Palgrave Macmillan.

Yurdakul, G., Römhild, R., Schwanhäusser, A., \& zur Nieden, B. (2018). Witnessing the transition: Moments in the long summer of migration. Berlin: Berlin Institute of Migration and Integration Research. Retrieved from https://edoc.hu-berlin.de/handle/18 $452 / 19415$

\section{About the Authors}

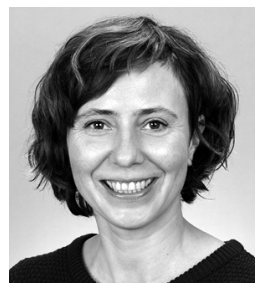

Ulrike Hamann (Humboldt-Universität zu Berlin) is a Research Associate at the Department of Diversity and Social Conflict at the Institute for Social Sciences and at the Berlin Institute for Integration and Migration Research (BIM). She holds a PhD from Goethe University in Frankfurt/Main in Postcolonial Studies. Her research focuses on questions surrounding migration, racism, housing, and urban neighbourhoods. She is also an activist for housing rights. In a current research project, she studies conditions for social cohesion and conviviality in different neighbourhoods, varying in terms of socioeconomic status and diversity, together with Nihad El-Kayed. 
Gökce Yurdakul is a Georg-Simmel Professor of Diversity and Social Conflict at the Humboldt Universität zu Berlin and the Chair of the Department on Foundations of Migration at the Berlin Institute for Integration and Migration Research (BIM). Her most recent book is The Headscarf Debates: Conflict in National Narratives (2014, Stanford University Press, with Anna Korteweg). She is currently conducting research on Contesting Authorities Over Body Politics: The Religious/Secular Tension in Germany, Israel, and Turkey funded by the German-Israeli Foundation (2016-18, co-investigator with Shai Lavi). 